\title{
Soft Skills as The People-Job Fit to Overcome Counterproductive Work Behavior in Credit Assessment Banking Sector: A Literature Review
}

\author{
Dewi Khrisna Sawitri \\ Post Graduate School \\ Universitas Airlangga \\ Indonesia
}

\begin{abstract}
Skills have been identified as a factor that has a role in work performance. Skills which are categorised into hard and soft skills play a beneficial role in determining the fit of people and the job at work while assessing credit, especially when they have to follow so many phases in assessing the information of the bank's customers. Many research findings show that soft skills have played more important roles than hard skills. A literature search was conducted to gather research from 1984 to 2016. This literature review discusses theories that focus on the urgency of soft skills for bankers and how they can be very beneficial to overcome counterproductive work behaviours. This review indicates that the lack of soft skills can have an impact on deviations in work behaviour since soft skills are intangible skills which relate with other people. In the banking sector, the job demands vary and cannot be neglected; they affect people in doing their job, as people always work with others. Furthermore, the concept can also be used to view how people-job fitness relates to soft skills. Journal reviews on counterproductive work behaviours have been elaborated on to find the relationship to bankers' soft skills. Some discussions and suggestions related to soft skills have also been provided for further research.
\end{abstract}

Keywords: counterproductive work behaviour, credit assessment, people-job fit, soft skills.

\section{INTRODUCTION}

Banking is a fast growing sector which deals with so many changes and involves many aspects of life. This sector has put its performance in credit as credit has been the indicator as to whether the bank has been managed well or not. The banks work by delivering credit to potential markets with new capital. Yanelle ${ }^{1}$ mentioned that new capital exists in the form of deposits to loans, which creates an opportunity for new investments. Loans are also risky since not all loans provided by the banks can be returned by the debtor as expected when they come to be due. Credit assessment plays a significant role in deciding whether the loan will be given or not to the borrower. In fact, the bank officers to this credit assessment must be the ones which are equipped with sufficient knowledge and skill so that they can perform well in doing their jobs. The employees' competency must be given attention since competency can lead to better performance at work. How the employees perform at work can also depend on the fitness of person-job. The objective of this research is to examine two important topics regarding the conceptualisation which has been the interest of the researcher. First, this paper will discuss the importance of counterproductive work behaviour in the banking sector, especially how it exists in the credit assessment process. Second, this paper also considers how the behaviours can be solved by implementing soft skills as it has shown to be the key to people-job fit in organisations.

Before we proceed, we have to comprehend that putting the right person on the right job is not just a metaphor, but that this really affects employees in performing the job. The concept of person-job fit may comprise of numerous ideas. According to Cable \& DeRue ${ }^{2}$, the needs-supplies fit discusses how good the environment fulfils the individuals' goals and values. Edwards et al. ${ }^{3}$, mentioned about the demands-abilities fit that is about the compatibility between the employees' KSAs and the formal job requirements. When understanding the complex environment faced by loan officers, KSAs are important to help them achieve the organisation's goals. NonPerforming Loans (NPL) have been identified as poor performance in the banking sector and these bad loans have been investigated by many researchers related to the skills of the credit officers themselves.

The lack of adequate skills possessed by credit officers is a factor which has been identified to have an effect towards Non Performing Loans in other countries ${ }^{4}$. Richard ${ }^{5}$, in her study, mentioned that very few respondents got training on relationship management, legal issues, management skills, change management and customer service. According to Prokopenko and Bondarenko ${ }^{6}$, the effective operational risk management environment in banking has strategies \& 
objectives to develop the relevant capabilities \& skills. Multiple skills are required such as know-how, self-learning capacity, and many others ${ }^{6}$. Lauver and Kristof-Brown ${ }^{7}$ stated that person-job fit is defined as the compatibility of the person's knowledge, skills, abilities (KSAs) and the demands of the job. This skill, what we know as one of the many job requirements, must be given attention by the employer since it is attached to the employee when conducting his job at work. Bank employees, especially ones who deal a lot with credit assessments, must be skilful since they will conduct many assessments deciding whether a future debtor is feasible or not. Ansari et al., ${ }^{8}$ hypothesised that skill variety is negatively related to the employees' CWB. People with varied skills can deal a lot with their job so they can manage negative feelings which can lead to deviant behaviour at work. People do not behave appropriately if they found that their skills are underused and they will feel angry, frustrated, bored and distressed when they are incapable of fulfilling their needs and qualifications ${ }^{9}$.

\section{METHODS}

This paper is a literature review since there have been many studies not only on CWB but also on credit assessment, people-job fit and soft skills. The process of gathering the literature has been limited to 1984 to 2016. The search of the literature was conducted using the key words 'credit assessment', 'people job-fit', 'soft skill' and 'counterproductive work behaviour' to identify the research topic. The search was not only in the form of journals but also textbooks, workshop/congress material, and other printed materials related to the discussion of this paper. Even though the topic is discussing human resources in the banking sector, the review was still open to all sectors and jobs related with the research key words. This was executed in order to explore more comprehension regarding with the topic.

\section{SOME ISSUES ABOUT COUNTERPRODUCTIVE WORK BEHAVIOUR IN THE CREDIT ASSESSMENT PROCESS}

Many studies have elaborated on counterproductive work behavior (CWB) focusing on the dark triad personality ${ }^{10}$, job stressors and organisational justice ${ }^{11}$, organisational citizenship behaviour $^{12}$, organisational citizenship behaviour, organisational behaviour ${ }^{13}$, and many others. Counterproductive behaviour has been indicated as being a deviant behaviour since this has led to people at work violating the organisations/ companies' rules and norms which has caused many losses. Deviant behaviour has been stated as voluntary that violates significant organisational norms ${ }^{14}$. Feldman ${ }^{15}$ stated that organisational norms are norms which comprise of basic moral standards as found in other traditional communities that include those prescribed by formal and informal organisational policies, rules, and procedures. Somehow, deviant behaviour, in the normative perspective, is human behaviour that violates the existing and accepted social norms ${ }^{16}$.
According to the workplace deviance framework, such behaviour has deviated from the formal and informal norms as prescribed by procedure, policy, and rules and somehow is not defined in terms of any system of moral standards ${ }^{17}$. In the organisational context, an employee which is found to be stealing compared to others who work under the rules can be considered to have shown deviant behaviour and what he does is "a deviance". However, stealing is interpreted as taking others' belonging without permission and is considered as deviant since it has violated organisational rules and norms. Not only stealing company belongings but taking their co-workers' belongings without permission is really breaking the norms and rules in any organisation. Kelloway et al., ${ }^{17}$ mentioned that behaviour is considered deviant if it harms not only the well-being of the organisation but its members as individuals as well. Workplace deviance is a pervading and costly problem for organisations ${ }^{18}$.

Fox and Spector ${ }^{19}$ mentioned that any deviances included in counterproductive work behaviour also related with property such as shirking, deliberate lateness and absence, stealing or the misappropriation of company property, as well as being aggressive or violent towards other employees. Greenberg and $\mathrm{Scott}^{20}$ mentioned that an employee was found to be stealing directly from other employees (in this case, the employee took cash from another employee's wallet) and somehow the employee was also found to be stealing the organisation's belongings (the employee took money from the cash register). Counterproductive work behaviours harm organisations badly ${ }^{21}$ and threaten the well-being of the organisation or its members, or both ${ }^{14}$. According to the definition of $\mathrm{CWB}$, it is obvious that such behaviour will cost extreme amounts of financial and non-financial problems to the organisation and its members ${ }^{22} . \mathrm{McGurn}^{23}$ mentioned that $75 \%$ of employees have reportedly stolen from their employer at least once. Harper ${ }^{24}$ stated that more than half of all employees have been involved in deviant behaviours such as theft, fraud, vandalism, sabotage, and voluntary absenteeism.

According to some of the literature, CWB has been categorised into multiple dimensions. Bennett \& Robinson ${ }^{18}$ has included both minor CWBs (for example: leaving work early, making and spreading rumours) and major CWBs (such as sabotaging work equipment, stealing money from the company). They also mentioned CWBs aimed at the organisation as a whole (CWB-Os) which includes stealing organisational property or wasting time at work and CWBs aimed at individuals inside the organisation (CWB-Is) that is about stealing the property of a co-worker or verbally abusing a co-worker. Gruys and Sackett ${ }^{25}$ classified CWB into behaviours related to job tasks (such as intentionally working slowly) or unrelated to job tasks (such as being involved in inappropriate physical or verbal actions towards others or destroying property). There are many other categories related to CWB. 
Credit assessment is not an easy thing to do since these assessments involve many phases before the bank decides to agree a credit proposal. The banking sector has absorbed much attention since this sector has been indicated to relate to deviant behaviour, not only ones that deal with financial looses, but looking thoroughly at the categories, working slowly at job tasks is also considered to be counterproductive. Major CWBs, that is stealing money from the company, is found to be a big concern in the banking sector. Fraud has serious consequences for the community in Australia, and has a hard effect, not only for the victims of fraud whose trust has been crossed or for the consumers who are responsible for the burden of business losses through increased costs and services ${ }^{26}$. Woods ${ }^{26}$ gave an example that happened in the United States. The American Bankers' Association in its ABA Banking Journal (August 1997) quoted a risk management employee of Wells Fargo Bank who had stated that US losses from cheque fraud alone were in the range of USD 10 billion to USD 50 billion. Since the banking sector centres on money transactions, bank workers seem to conduct fraudulent activities most often. According to Benjamin and Samson $^{27}$, sales fraud generally happens in financial institutions since there is an absence of credit control that exists between a customer and a staff member. This fraud also includes raising false credit notes or generating a reduction in the customers' debt, as well as illegal access to cash receipts ${ }^{27}$. Mentioning how credit assessment works, it is important to note that the doers in banking sectors can be part of counterproductive behaviour if they, for some reason, are not assessing credit as ruled by the institution.

As mentioned by Sinkey $^{28}$, credit assessments can have two possible outcomes, not only to approve credit for appropriate customers but also to judge potential good borrowers as inappropriate ones, and to reject credit. Credit Assessors, in this case, can involve a bank marketer, credit supervisor, and somehow this can be a branch manager too. They all have the potential to perform counterproductive work behaviours, if they are not following the right rules to assess credit worthiness. Bruns ${ }^{29}$ stated that to avoid problems and to look at whether a customer's credit proposal is worthy; the banks have to collect the necessary information in order to make a good judgement. There are two types of risks related with the bank (as the lender); collapsing to detect a borrower who is unworthy and untrusted (moral hazard) and agreeing a loan that is unworthy (or we can say it as adverse selection) ${ }^{30}$.

\section{SOFT SKILLS AS THE KEY TO PEOPLE-JOB FIT AS THE SOLUTION TO CWB}

Jobs are demanding. Nowadays, jobs are improving day by day as the industry is entering in to more competitive markets. There are many operational jobs which cost a lot to cover. Somehow, as there are so many challenges, the organisation and industry as a whole have tried their best to match the people to whom they work for and the jobs in which they must be responsible for. Mismatches between people and jobs may exist if the employer or the management is not aware with the importance of fitness. When people fit the job, the job performance can be enhanced. Many studies have elaborated on person-job fit focusing on selection and socialisation ${ }^{31}$, psychological climate adjustment, personality traits, innovative climate $^{32}$, job crafting, demands-ability and need-supply ${ }^{32}$. Person-Job fit matches the person's ability with the job demands $s^{33}$. The person who is working may have a lot of skills but the needed skill is a skill which relates a lot with the job tasks.

Kristof-Brown ${ }^{34}$ defined person-job fit as the match between people who work and the jobs that they do. It can also be the fit between the person's ability and the job demand ${ }^{35}$. Demand-ability fit refers to the fitness between the employee's knowledge, skills, and abilities, and the demands of the job ${ }^{36}$.

Skill is what the worker needs to perform the jobs and to use their knowledge effectively ${ }^{37}$. Armstrong ${ }^{38}$ has categorised competency into soft skills (behaviour competency), hard skills (technical competency), and vocational competency. Skills can also be classified into basic skills such as reading, counting; and generic skills such as team work and communications which are implemented at work $^{39}$. Others can be categorised into hard skills and soft skills. Shakir ${ }^{40}$ stated that hard skills usually refer to technical procedures or practical tasks that are usually easy to observe, measure and soft skills, commonly referred to as 'people skills', are not easy to learn even though these skills are very much needed in working life. Numerous studies have emphasised the importance of soft skills in professional occupations as well as the value placed by the owner of the company on them ${ }^{41}$.

For current and future business leaders, soft skill development is important because it is critical for productive performance at work $^{42}$. According to Robles ${ }^{43}$, soft skills include character, attitude, and behaviour rather than technical or knowledge skills. Soft skills are described as intangible, non-technical and certain personalities that help to ensure a person's strength in leadership, facilitating, mediating and negotiating ${ }^{44}$. Soft skills are important when mastered by professionals working in various fields as well as in the banking sector. Employees conducting credit evaluation process should understand and be able to conduct an assessment of the creditworthiness proposed by customers. The process of credit assessment involve activities such as to collect and verify information, documents; to analyse and to approve credit; to administer and to record credit; to monitor credit, to pay and to recover credit. Soft skills play an important role since all of those processes deal with customers or other parties which relate a lot to people skills. Employees who are responsible for credit assessment must be equipped with the skills to fit with the job. But in practice, many banks do not consider credit officers with analytical and experiential skills and emphasise only the qualifications of their employees' previous business history ${ }^{45}$. 


\section{SUMMARY AND RECOMMENDATION}

Banks, as the main doers in the economy, have an important role in the credit market ${ }^{46}$. Credit assessment in the banking sector is a risky job task since this task will result in decisions as to whether credit is given to the borrower or not. Credit officers will have to evaluate all of the needed information before a decision is made. Credit officers have the main job of evaluating a potential borrower's application, assessing its credit risk and then making a loan recommendation ${ }^{47}$. Then the credit officer will provide the decision about the borrower's financial statements, which allows them to evaluate their current cash flows, predicting future cash flows, and assessing their ability to serve the debt when due ${ }^{47}$. If the assessment is bad, then the credit proposal may be rejected ${ }^{28}$. This is why credit assessment is risky and the person who is involved in the job has many chances to perform counterproductive work behaviour. It is very important for any researcher to conduct research on why credit assessment is so risky which can lead to counterproductive work behaviour. Any findings that can elaborate on how this behavior can be directed to the organisation or even to an individual at the organisation can provide a meaningful contribution to the banking sector.

Counterproductive work behaviour is a kind of deviant behaviour which is found to cause financial losses. Financial institutions generally experience sales fraud ${ }^{48}$. Benjamin and Samson ${ }^{48}$ mentioned that a staff member can raise false credit notes or generate a reduction in the customers' debt, as well as illegal accesses to cash receipts. Person-Job fit is meaningful to perform job tasks well, especially in credit assessment. Credit officers as people who evaluate credit must be skilful especially in dealing with the customer. The officers must be able to collect the customer's information as much as they can since the information plays a significant role in determining either the customers' credit proposal is accepted or not. People skills are needed and must be considered as being the main skill owned by credit officers. Credit management in the future should consider hiring loan officers who strong analytical skills and experience in the credit section as there seems to be a lack of human resources in the event of failure in banks ${ }^{45}$. $75 \%$ of long term job success depends on people skills (soft skill), while only $25 \%$ depends on technical knowledge ${ }^{49}$. Building soft skills for credit officers is essential in order for them to be able to perform credit assessments. For further research, the importance of building soft skills as the indicator of person-job fit must be given priority since this will allow us to observe how far people skills can be helpful to minimise deviant behaviour when assessing credit.

Other variables are found to be important in dealing with CWB. Jung ${ }^{50}$ mentioned that in service-oriented businesses such as hotels, employees give service directly to the customers; in that way, emotional intelligence (EQ) has a beneficial role in controlling emotions. Other research is expected to focus on EQ to find out how it can affect CWB.

\section{REFERENCES}

1. A. Cohen. "Are they among us? A conceptual framework of the relationship between the dark triad personality and counterproductive work behaviours", Human Resource Management Review, 26, 69-85, 2016.

2. A. Guiral, E. Ruiz, and H. L. Choy, "Information content of Going Concern Audit Reports and the provision of Non-audit services in Credit Decisions: A Lending Knowledge Structures Approach", Presented at the 33rd Annual Congress of the European Accounting Association, Istanbul, 2010.

3. A. Kristof-Brown, "Person-job fit", In S. Rogelberg (Ed.), Encyclopedia of industrial and organizational psychology, pp. 619621, 2007.

4. A. Luksyte, C. Spitzmueller, and D. C. Maynard, "Why Do Overqualified Incumbents Deviate?" Examining Multiple Mediators. Journal of Occupational Health Psychology, Vol. 16, No. 3, 279-296, 2011.

5. C. Nealy, Integrating soft skills through active learning in the management classroom. Journal of College Teaching \& Learning, 2(4), 1-6, 2005.

6. D. Cable, and D. DeRue, The convergent and discriminant validity of subjective fit perceptions. Journal of Applied Psychology, 87, 875-884., 2002

7. D. C. Feldman, "The development and enforcement of group norms", Academy of Management Review, 9, 47-53, 1984.

8. D. Harper, "Spotlight abuse-save profits", Industrial Distribution, 79, 47-51, 1990.

9. D.M Cable, and T.A. Judge, "Person-organization fit, job choice decisions, and organizational entry". Organizational Behaviour and Human Decision Processes, 67, 294-311, 1996

10. E. L. Levine, "Emotion and power (as social influence): Their impact on organizational citizenship and counterproductive individual and organizational behavior", Human Resource Management Review, 20, 4-17, 2010.

11. E. K. Kelloway, et al., "Counterproductive work behavior as protest", Human Resource Management Review, 20, 18-25, 2010.

12. E. Richard, "Factors That Cause Non- Performing Loans in Commercial Banks in Tanzania and Strategies to Resolve Them". Journal of Management Policy and Practice, vol. 12(7), 2011.

13. F.H. Lee, and W.Y. Wu, 2011, "The relationships between personorganization fit, psychological climate adjustment, personality traits, and innovative climate: Evidence from Taiwanese high-tech expatriate managers in Asian countries". African Journal of Business Management, Vol. 5(15), pp. 6415-6428, 2011.

14. G. Dell'ariccia, and R. Marquez, "Lending Booms and Lending Standards", Journal of Finance, 61(5), 2511-2546, 2006.

15. H.S. Jung, and H. H. Yoon, " The effects of emotional intelligence on Counterproductive work behaviors and organizational citizen behaviors among food and beverage employees in a deluxe hotel". International Journal of Hospitality Management, 31, 369-378, 2012. 
16. I.N. Esther, "Factors Contributing to Non-Performing Loans in Commercial Banks in Kenya", Scholar Journal of Economy Business Management, 2014; 1(6):227-234, 2014

17. I. Woods, "Fraud and the Australian banking industry". presented at the conference crime against business, the Australian institute of criminology, Melbourne, June, 18-19, 1998.

18. J.A. Chatman, "Matching People and Organizations: Selection and Socialization in Public Accounting Firms", Administrative Science Quarterly, 36, 459-484, 1991.

19. J.A. Humphrey, and F. Schmalleger, "Deviant Behavior", Second Edition, Jones \& Bartlett Learning, 2011.

20. J. Edwards, D. Cabe, I. Williamson, L. Lambert,, \& A. Shipp, The phenomenology of fit: Linking the person and environment to the subjective experience of person environment fit. Journal of Applied Psychology, 91, 802- 827, 2006.

21. J. Greenberg, and K. S. Scott, "Why do workers bite the hands that feed them? Employee theft as a social exchange process", In B. M. Staw \& L. L. Cummings (Eds.), Research in organizational behavior, Vol. 18, pp. 111-156, Greenwich, CT: JAI Press, 1996

22. J. M. Jensen and J. L. Raver, "When Self-Management and Surveillance Collide: Consequences for Employees' Organizational Citizenship and Counterproductive Work Behaviors", Journal on Group \& Organization Management, 37(3), 308- 346, 2012.

23. J.R Edwards, "Person-job fit: A conceptual integration, literature review, and methodological critique", In C.L. Cooper \& I.T.Robertson (Eds.), International review of industrial and organizational psychology, Vol.6, 283-357, New York:Wiley, 1991.

24. K. J. Lauver, \& A. Kristof-Brown, "Distinguishing between employees' perceptions of person-job and person-organization fit". Journal of Vocational Behaviour, 59(3), 454-470., 2001.

25. K.R. Murphy, "Honesty in the Workplace". Brooks/Cole, Belmont, Pacific Grove, California, CA, 1993.

26. L.Sandy. "Prosperity for all in the global economy - world class skills". The Leitch Review of Skills, 2006, Available at: hmtreasury.gov.uk/leitch

27. M. Armstrong, "A Handbook of Personnel Management Practice", Kogan Page, 1992.

28. M. Armstrong, "A Handbook of Human Resource Management Practice". 10 $0^{\text {th }}$ Edition, Kogan Page Limited, 2006

29. M. E. Ansari, et.al., "Individual, Job, and Organizational Predictors of Counterproductive Work Behavior", Journal of Basic and Applied Scientific Research, 3(4), 78-86, 2013.

30. M. L. Gruys, and P. R. Sackett, " The dimensionality of counterproductive work behavior", International Journal of Selection and Assessment, 11, 30-42, 2003.

31. M-O Yanelle,." The Strategic Analysis of Intermediation. European Economic Review, 33(2,3), 294-302, 1989.

32. M. Robles, "Executive Perceptions of the Top 10 Soft Skills Needed in Today's Workplace", Business and Professional Communication Quarterly, vol. 75 no. 4 453-465, 2012.

33. M. Tims et al., "Job crafting and its relationships with person-job fit and meaningfulness: A three-wave study", Journal of Vocational Behavior, 92, 44-53, 2016
34. N. M. Waweru and V. M. Kalani, "Commercial Banking Crises In Kenya: Causes And Remedies", African Journal of Accounting, Economics, Finance and Banking Research, Vol. 4., No. 4,. 2009

35. N. Seetha, "Are Soft skills Important in the Workplace? - A Preliminary Investigation in Malaysia”. International Journal of Academic Research in Business and Social Sciences, April 2014, Vol. 4, 2014

36. O. A. Benjamin, and B. S. Samson, "Effect of perceived inequality and perceived job insecurity on fraudulent intent of bank employees in Nigeria", Europe's Journal of Psychology, 7(1), pp. 99-111, 2011.

37. P. Klaus, Communication breakdown. California Job Journal, 28, $1-9,2010$.

38. R. J. Bennett, and S.L. Robinson, "Development of a Measure of Workplace Deviance", Journal of Applied Psychology, Vol. 85, No. 3, 349-360, 2000

39. R. Lipshitz and N. Shulimovitz. "Intuition and Emotion in Bank Loan Officers' Credit Decisions", Journal of Cognitive Engineering and Decision Making, Volume 1, Number 2, , pp. 212-233, 2007

40. R. Shakir, "Soft skills at the Malaysian institutes of higher learning", Asia Pacific Educ. Rev., 10:309-315,2009.

41. S. Fox, P.E. Spector, "A model of work frustration-aggression". Journal of Organizational Behavior, 20 (6), 915-931, 1999.

42. S. Fox, P. E. Spector and D. Miles, "Counterproductive Work Behavior (CWB) in Response to Job Stressors and Organizational Justice: Some Mediator and Moderator Tests for Autonomy and Emotions", Journal of Vocational Behavior 59, 291-309, 2001

43. S. Johnston and H. McGregor. "Recognizing and Supporting a Scholarship of Practice: Soft Skills are Hard!" Asia-Pacific Journal of Cooperative Education, 6(1), 1-6, 2005

44. Sinkey, J. F. "Commercial Bank Financial Management in the financial industry", 4th edition, New York: MacMillan Publishing Company, 1992.

45. S. Robinson \& R. Bennett, "A typology of deviant workplace behaviors: A multi-dimensional scaling study", Academy of Management Journal, 38, 555-572, 1995

46. S. Vatankhah, E. Javid, and A. Raoofi, "Perceived organizational support as the mediator of the relationships between highperformance work practices and counter-productive work behavior: Evidence from airline industry", Journal of Air Transport Management 59, p.107-115, 2017.

47. T.Sekiguchi, "Person-Organization Fit and Person-Job fit in Employee Selection: A Review of The Literature", Osaka Keidei Ronshu, Vol.54, No.6, March 2004.

48. V. Bruns, "How Receive Bank Loans?”, JIBS Research Reports, 2004.

49. X. McGurn," Spotting the thieves who work among us". Wall Street Journal, p. 16a, 1988.

50. Y. Prokopenko, D. Bondarenko, Operational Risk Management: Best Practice Overview and Implementation. Presented at Risk Professional Workshop, International Finance Corporation: World Bank Group, Tirana, Albania, September 10-11, 2012. 